\title{
POLICY FORMULATION MODEL BASED ON DELPHI ENGINEERING (Case Study of Bioterrorism in Law Number 5 Year 2018)
}

\author{
Arie Herumurti \\ Student of Doctor Study Program of Administration Sciences - FISIP, Universitas 17 Agustus 1945 \\ Surabaya, Jl. Semolowaru No. 45 Surabaya, Jawa Timur, Indonesia \\ V. Rudy Handoko
}

ABSTRACT

Achmad Sjafi'i, SH., M.Si

\begin{abstract}
As time goes on, spreading terrorism does not only use violence or destruction on certain objects, but has changed its form based on the goal to be achieved. Bioterrorism is an example of the terrorism method by using the means of living things in carrying out their actions.Until now, the terrorism crime prevention law seems to be difficult to ensnare the perpetrators who commit crimes that lead to the actions of the Bioterror. The initial estimation of researcher is to lead to the definition of terrorism which is still cramp. This research uses Qualitative Descriptive Phenomenology Method Case Study.Based on the results of the study, the roots of the problems that occur in the policy formulation process which imply that the terrorism law has not been optimal are 1) inadequate human resources, 2) the involvement of weak network groups have not been optimal, and 3) retrieval using statistical methods. The conclusion of this study is to get optimal results therefore the policy formulation processes that need to be done are: human resource improvement, involvement of weak network groups in policy formulation, and the use of new methods namely Delphi techniques in the decision-making process at the executive level.
\end{abstract}

Keywords: terrorism, bioterrorism, policy formulation, Delphi.

DOI: $10.7176 /$ PPAR/9-7-07

Publication date:July $31^{\text {st }} 2019$

\section{Introduction}

1.1 Background

Public policy is an indispensable subject for national scale development. Without a policy, the development system in the country of Indonesia will not be able to compete and make all the accuracy directed. All forms of the process of implementing development in Indonesia depend on how the policies are issued by the government itself. Every policy certainly needs an assessment after the policy is implemented. This is because in general a policy will be issued in line with the progress and development of the strategic environment around it.

The current development of the strategic environment has a very dominant influence on world security. Increasing the strength of a country's armed forces has created a security dilemma for countries in the region. Conflicts that occur in the region also increase the sense of awareness for the surrounding countries. This condition will change the dimensions of the threat which is no longer traditional and more hybrid. In order to prepare strength and ability in order to anticipate and deal with the development of the threat dimension, predictions of threats are needed, both global, regional and national threats.

Terrorism is a threat to human civilization throughout the world. This action has the potential to disrupt the security stability of a country, even affecting regional and global stability. Behind this actual terrorist threat, it is also necessary to take into account Proxy War in the context of terrorism, where terrorism groups are intentionally used by other parties as a justification for making certain responses as a form of the Responsibility to Protect against their citizens or national interests. According to Webster's New World College Dictionary (1996), the definition of Terrorism is "the use of force or demoralize, intimidate, and subjugate. The doctrine distinguishes Terrorism into two kinds of definitions, namely the definition of terrorist acts and terrorism actors. It was agreed by most experts that actions belonging to Terrorism actions are actions that have elements: political goals, and terror / intended audience.

Over time developing terrorism not only uses violence and destruction on certain objects, but has changed its form according to the objectives to be achieved, for example the use of microbes and bacteria in order to destroy agricultural land by planting vegetable seeds that have been inseminated with bacteria therefore agricultural products the country is destroyed or by spreading certain viruses in an area thus causing public health in the region to be disrupted or even worse causes many casualties. This form of terror is known as Bioterrorism. Bioterrorism means the use of microbes as a means of terrorism. Microbes used in bioterrorism are 
more popular in the mass media as biological weapons or bioweapons. War involving biological weapons / microbes is called germ warfare or the biological warfare (Nester et al., 2007; Tortora et al., 2007).

Currently in Indonesia, the law that is used as a legal umbrella in carrying out acts of Terrorism is Law Number 5 of 2018. This Law is a change to Law Number 15 of 2003 concerning the Establishment of Government Regulations in lieu of Law Number 1 of 2002 concerning Eradication of Criminal Theorism. In Law Number 5 of 2018 in Chapter I General Provisions, Article 1 paragraph 1, is stated; Terrorism Crimes are acts that use violence or the threat of violence that creates an atmosphere of terror or widespread fear, which can cause mass casualties and / or cause damage or destruction to strategic vital objects, the environment, public facilities or international facilities with political, ideological or security disturbances.

However, the fact is that the implementation of the terrorism law has not been able to accommodate the handling of theorism actions using the media of living things or bioterrorism. As an illustration, since the issuance of Law Number 15 of 2003 concerning the Eradication of Criminal Acts of Terrorism in Indonesia, there have been several incidents that have led to the actions of Bioterrorism. Based on initial predictions, the reason that causes the difficulty of the legal process for perpetrators of Bioterrorism is the definition of terrorism itself. The definition of terrorism seems to be locked in "acts that use violence or threats of violence". On the other hand, Bioterorism in carrying out its activities is very far from violence or the threat of violence, even though the impact is the same namely the destruction or destruction of target objects.

In relation to the topics discussed, the researchers see the weakness of the definition of terrorism that exists today due to the process of policy formulation that is not optimal in the executive ranks. The process of discussion is so tough and long by bringing each other's interests to birth policy conflicts between institutions which ultimately lead to the output of the formula to be biased. In addition to this, in the formulation of policies, the terrorism law does not involve stakeholders in full. Weak network groups as mentioned in the Granoveter network theory are not involved in the policy formulation process. This resulted in policy output becoming less comprehensive.

Based on the preliminary findings above, the researchers sought to explore and then discuss how to modify the current policy formulation model with a more applicable approach and able to accommodate the ideas of all elements involved by raising a case study of the application of Bioterrorism in the terrorism Act container.

\subsection{Problems}

Based on this background, the research questions can be formulated as follows:

1. How is the policy formulation solution in solving public problems?

2. How is the policy formulation model for handling acts of terrorism in Indonesia based on the Delphi method?

1.3. Aims and Objectives

1. Analyze policy formulation solutions in solving public problems.

2. Model formulation of policies for handling acts of terrorism in Indonesia based on the delphi method 1.4 Benefits of Research

\section{Concept of thinking}

2.1 Concept of public policy

Understanding Policy before discussing further about the concept of public policy, we need to first assess the concept of policy or in English we often hear the term policy. In the Big Indonesian Dictionary, policy is defined as a series of concepts and principles that form the outline and basis of the plan for implementing a job, leadership, and how to act (about government, organization, etc.); statement of ideals, goals, principles and guidelines for management in an effort to achieve the goals. Carl J Federick as quoted by Leo Agustino (2008: 7) defines policy as a series of actions / activities proposed by a person, group or government in a particular environment where there are obstacles (difficulties) and opportunities for implementing the proposed policy in order to achieve certain goals. This opinion also shows that the idea of a policy involves behavior that has a purpose and purpose is an important part of the definition of policy, because after all the policy must show what is actually done rather than what is proposed in some activities on a problem.

2.2 Policy Formulation

Policy formulation is the earliest step in the overall public policy process. Therefore, what happens in this phase will determine the success or failure of the public policy made in the future. According to Joko Widodo, 2007 in Kadji (2007) that public policy formulation processes go through four stages, namely as follows: (1) problem identification, (2) agenda setting, (3) policy problem formulation, (4) policy design.

a. Problem identification or problem identification is to carry out the introduction and understanding of problems and mapping problems by examining and recognizing any changes that occur in both the internal environment and the external environment. Not all public problems can move many people to come to think about and find solutions that can appear to be a policy problem (only 
those that move people to action become polily problems). Therefore, the most important concept is that a public problem can become a policy problem, it is not enough to be lived by many people as a problem, but the community also needs to have political will to fight for general problems to become policy problems and more importantly also positive response from policy makers

b. Setting an agenda or agenda setting is a term that is generally used to describe a content that is considered public needs to be taken an action. Agenda as a general agreement about the existence of a public problem that needs to be a common concern and according to government intervention to solve it (Kadji, 2007: 12). Preparation of a policy agenda begins with a problem that appears in the community. This problem can be expressed by someone as a public problem, for example the problem has a large impact on the people, there is convincing evidence that the legislative and executive institutions and observers of the problem are serious problems, and there are easy-to-understand problem solving problems and noticed.According to Andersen in Joko Widodo (2007: 53), that the agenda of setting in a coherent manner consists of: (a) private problems, (b) public problems, (c) political issues, (d) systematic agenda, (e) institutional agenda. Private problems are problems that have limited consequences, or only involve one or a small number of people who are directly involved. Public problems are problems that have broader consequences including the consequences of those who are indirectly involved. Political issues are differences of opinion of the community about solutions in dealing with problems (policy action), systematic agenda is an issue felt by all citizens of the political community who deserve public attention and the issue is within the jurisdiction of government authority. Institutional agenda is a series of issues that explicitly require active and serious considerations from legitimate / authoritative decision makers.

c. Formulation of public policy problems, William Dunn (1998: 244) distinguishes four types of interdependent phases, namely (a) problem finding, (b) problem definition, (c) problem specification, and (d) problem recognition. The four phases are related to problem situations, meta problems, substantive problems, and formal problems.

d. Policy Design. The purpose of this activity is that each alternative that has been collected by the decision maker seems to be clearly understood. The more clearly the alternative is defined the easier it is for policy makers to assess and consider the positive and negative aspects of each of these alternatives. Conversely, alternatives that cannot be defined or formulated well will not be used properly as an alternative policy to solve problems. The step after determining the formal problem, then the next step is to determine the purpose and formulation of alternative objectives

Technical Feasibility is to see the extent to which each alternative policy can achieve its intended goals and objectives, this assessment criterion emphasizes the effectiveness aspects of an alternative step of intervention in achieving what has been set goals and objectives. Economic and financial feasibility is to see the extent to which each alternative policy requires costs, and how much profit can be obtained from each alternative policy. Political Viability is to see how far the effects and impacts of each policy alternative. The political impact of alternative policies will be seen from the level of accessibility, compatibility with values in society, responsiveness, conformity with legislation and equity. In essence this alternative aims to get political support or sponsorship of the proposed alternative. While Administrative Operability sees how likely an alternative policy can be successfully implemented in the prevailing political, economic, social and administrative contexts. This dimension of the administrative operability will look at the dimensions of the authority of the implementing agency, institutional commitment, staff and fund stability, and organizational support.

\section{Materials and Methods}

3.1 To be able to conduct research related to the theme "Model Policy Formulation of Law Number 5 of 2018 concerning Eradication of Terrorism in Indonesia" the researcher used the Fenomology case study model approach. In the view of the phenomenology paradigm, what is visible or visible in its essence is not something real (reality). It's just a reflection of what's inside. The task of the Case Study researcher is to explore something that does not appear to be visible knowledge. Therefore Case Studies can be interpreted as a process of reviewing or understanding a case and at the same time looking for results. Regarding research topics, to modify the current policy formulation model to obtain comprehensive product policy formulation researchers use the Delphi technique in the policy formulation process. This technique is carried out by combining the ideas of all stakeholders involved in the tabulation of data before finally being summarized into a single product bill to be submitted in a session in the DPR

The object of this policy research was carried out in the Porong Sidoarjo prison, the Indonesian Ministry of the Republic of Indonesia, the National Police, and other institutions which were considered to meet the related requirements for the topics discussed. The choice of location or site selection according to Sukmadinata (2007: 102) relates to the determination of units, parts, groups and places where people are involved in the activities or events that will be studied. As a basis for making the desired policy formulation, this research will 
discuss the content / contents of Law No. 5 of 2018 concerning the Eradication of Terrorism Crime, Law No. 9 of 2013 concerning Prevention and Eradication of Terrorism Funding Crimes, and Law No. 16 of 1992 concerning Animal Quarantine, fish, and plants. In this study the authors used a non-probable sample, meaning that not all populations have the same opportunity to be chosen as key informants. Determination of informants is done intentionally (purposive sampling) where the author determines the informant himself, assuming that the informant understands the problem being studied and can provide information and responses to the problems that are the objectives of this study. The informants chosen in this study included officials in the Indonesian Ministry of the Republic of Indonesia, the National Police, and selected people who were considered eligible to be appointed as informants in this study.

From different informants as above, checking the truth from one source to another source is carried out. Thus, data or information about something in common can be compared. Through this method, it is expected that collected data can be trusted more truthfully, and the subjectivity of researchers or information sources can be avoided. Likewise for activities observed or observed are activities related to the implementation of the program such as analysis of the contents of the planning documents and the implementation of activities from the running program.

\section{Results and Discussions}

4.1 Policy Formulation: Terrorism Law

Based on the explanation in the previous chapter, it was stated that the policy on eradicating terrorism in Indonesia had undergone several changes. These changes are a form of government efforts on the development of terrorism itself. But as with other studies, in this study researchers will criticize the tendency of weak process of policy formulation at the executive level, especially related to the content of Bioterrorism in the Act on terrorism in Indonesia.

\subsection{Results}

Based on the data obtained, the researchers looked at the process of policy formulation carried out at the executive level not yet optimal in accommodating community input and elements from other institutions such as the Ministry of Health and the Ministry of Agriculture. Even though the input could have been possible to be taken into consideration in the context of the formulation of the terrorism law in a broader sense. This is in line with that as stated by Granoveter in network theory stating that weak bonds can be a very important part. The role of actors in weak network ties can help as a bridge (catalyst) between groups that have strong internal ties. Without such weak ties, the two groups might be totally isolated. This isolation can further cause the social system to become more fragmented.

Based on the description above found the root of the problem which is the cause of the lack of optimal output of policy products, namely:

A. Inadequate human resources (HR)

As we know, human resources are very vital.

The impact of inadequate human resources, one of which is the occurrence of power struggles against the background of policy conflicts in the process of policy formulation which have an impact on the bias in the output of policy draft output. This conflict will not occur if there is a previous consensus that integrates the interests of political actors in it. As Maswadi Rauf stated, political conflict is not a personal conflict, but rather a group conflict because each conflicting individual represents the interests of their respective groups.

The ability of human resources to understand the meaning of language and put it in a policy brings tremendous impact. The language contained in a policy has a vital impact on the continuity of a nation. The structure of the language compiled into a policy can increase authority, to increase the fear of foreign interests and nations. As stated by Muridan S. Widjojo in his book "State Language versus the Language of Student Movement" which cites Pierre Bourdieu's statement as follows: "Pierre Bourdieu considers that power is the main goal in every social relation. Every social relation, there are always battles whose ultimate goal is to gain power. In the context of social relations, language has a language arbitration, that is, there is no similarity between grammatical rules and their meanings, but more important is the purpose of that meaning.

Some people are less aware that the language contained in the contents of a policy will have a major influence on the survival of the Nation. The narrow definition of the current terrorism law has a major impact on the survival of the nation in the present and in the future. Through understanding the language and symbol of power, it is expected to be able to see the symbolic power of language in the practical order in the next section. This study is expected to be a guide to explain the logic of language as a symbol of power. Mainly the function of language work in the context of maintaining power. Power referred to in the context of this policy formulation is power in maintaining sectoral ego in the implementation of the policy formulation process. This has an impact on the concept proposed in the DPR session not comprehensively. 
B. The involvement of weak bonding network groups is not optimal

As explained earlier, the weak bond network group (Ministry of Health and Ministry of Agriculture of the Republic of Indonesia) has not been optimally accommodated in the process of formulating the Terrorism Law. This has resulted in monotonous and less flexible output of policy products. The definition of terrorism enshrined in Law Number 5 Year 2018 is still considered weak. Terrorism seems to be locked in acts carried out by violence and or threats of violence. Whereas in the case of the threat of Bioterrorism, this terror can be carried out by methods that are very far from violence.

According to the researcher, this will be easier if the network of weak ties is actively involved since the beginning of policy formulation or even involved in formulating the agenda setting in determining the objectives of the Terrorism Act. But in reality if faced with the objectives to be achieved as originally formulated, then this policy seems to only accommodate Terrorism within the scope of the simplest definition, therefore the ultimate goal of dealing with terrorism has a gap. The formulation of the articles of the terrorism law seems to only prioritize the legal language in the threat paradigm within the sectoral scope, without the existence of a new environmental paradigm that lies behind it in a reflective and progressive manner.

C. Decision Making Method in Static Formulation Stage.

As Hogwood said, a policy will not work perfectly because there is rarely a general agreement between the actors about the objectives of the policy and how to achieve it. In formulating a policy, it is not uncommon to argue with an argument involving the participants by carrying their own foundation. This has an impact on the resulting output that is not able to accommodate the desires of the discussion participants. In the case of the formulation of the Terrorism Law for example, based on the information obtained it was found that the discussion situation occurred so hard. Especially between the TNI, the Ministry of Defense and the National Police. TNI and Ministry of Defense see terrorism as a form of threat that is globally oriented and is not solely touched by the approach of ordinary crime. On the other hand, Polri believes that based on literature, legal studies, and the existing historical foundation, it is necessary to understand that the National Police must require convenience in the prosecution process therefore later it will not backfire for the Indonesian Police and the eyes of the world because it is vulnerable to human rights violations.

A thought is needed in order to evaluate the method that has existed today with a more modern method, although it still carries the value of Indonesian tradition, namely the concept of consensus meeting.

\section{Research Findings}

Based on the results of observations and the findings of the existing problems indicate that there are several important findings in this study:

1) That in the process of policy formulation a method of decision making is needed that is able to accommodate the concept of ideas from all stakeholders.

2) That the delphi technique is a model of decision making that is able to answer the obstacles in the current policy formulation process.

\section{Implications of Theory and Policy}

The implications of the results of this study include two implications, namely theoretical and practical implications. Theoretical implications related to its contribution to the development of public policy formulation theory, human resource improvement, optimization of involvement of weak network groups in the process of policy formulation, and decision-making procedures to produce comprehensive policy products. While the practical implications relate to the contribution of research to the involvement of all elements to strengthen BNPT in providing ideas for dealing with terrorism in Indonesia.

\subsection{Theoretical implications}

Based on the results of the study showed that HR, involvement of network groups is weak, and decision-making techniques influence the results of public policy formulations. This can be explained as follows:

1) This research has proven that the human resources involved in the process of policy formulation are not optimal. This can be seen from the tough and long process of formulation carried out at the executive level to the legislative level. The course of the discussion can not be separated from the impression of mutual attraction of interest without regard to the impact it causes. In general, the visible impacts are products that seem sectoral and less comprehensive.

2) This research has proven that the involvement of weak network groups, or in this case institutions outside the ranks of the Coordinating Minister for Political, Legal and Security Affairs was not involved in the process of policy formulation from the start in the Coordinating Minister for Politics and Security. Two institutions that researchers consider to have an important role despite being outside the strong network / core are the Ministry of Health and the Ministry of Agriculture. These two ministries seem to 
have no direct relationship with the topic discussed, namely terrorism. Even though in reality these institutions are actually able to become the catalyst or bridge the problems in the discussion room. Several national and international incidents have been victims of acts of terrorism that have led to Bioterrorism, and this has to do with the fields of human health, animals and agriculture.

3) In formulating policies implemented by the government, there are obstacles in the process of policy formulation. The current rules of the game are still using the old method, namely through the discussion method. This method is in fact often an arena for arguing the discussion participants in maintaining opinions as well as their respective professional and scientific backgrounds. As a result of this, at the end of the discussion the output of draft products became less comprehensive. The Delphi technique is one of the relevant methods or methods to solve the above problems. The idea of all discussion participants who are experts in the field of profession each is given space to put their ideas into data tabulation. The ideas and all information poured into the data tabulations are exchanged with each other by giving comments to each other. The results of filling in the tabulation will be returned to the fillers for refinement. At the end of the tabulation the ideas of all stakeholders were collected and summarized. The final results are expected to contain all the comprehensive ideas of all stakeholders.

\subsection{Practical Implications}

The results of this study have implications for the process of formulating Terrorism Law policies for:

1) The need for input from all elements of both the government and the community regarding the topics discussed. It is useful to consider and decide which institutions are needed to be involved in the meeting on drafting a policy on terrorism law.

2) From the input of all elements including community input, it can also be used as a guideline for BNPT (National Counter Terrorism Agency) to add personnel from institutions other than those currently existing (TNI and Polri).

3) The need for the implementation of the Delphi technique in making decisions in the process of formulating the terrorism law.

\section{Conclusion}

Based on the phenomological method approach in the Bioterorism case study in Law Number 5 of 2018, a number of conclusions can be drawn from the research on modification of policy formulation models, including:

1) To obtain optimal results in the process of policy formulation, it is necessary to increase human resources, involve weak network groups in policy formulation, and use new methods in the decisionmaking process at the executive level.

2) The Delphi method is considered to fulfill the requirements to summarize the ideas of all the institutions involved, therefore the output produced is able to represent all interests. Modification of the decision-making model from what is currently available is generally carried out by including all the ideas and ideas of the discussion participants that are limited by the instruments made by experts as guidance. Furthermore, these ideas are included in the tabulation of data and distributed to all stakeholders by giving one another one another. The results obtained in the end are all the ideas of the stakeholders.

\section{BIBLIOGRAPHY}

Adi Prasetyo. (2008). Tinjauhan hukum terhadap Bioterrorism Act sebagai hambatan non tarif terhadap perdagangan Internasional.

Ahmad Sururi. (2017).Modifikasi Model Formulasi Kebijakan Perencanaan Pembangunan Perdesaan Berbasis Partisipasi Publik .

Andi Rahmat Hidayat, Alwi Alwi, Gita Susanti. (2015). Model Jaringan Kebijakan Publik (Perumusan Kebijakan Masyarakat Adat Ammatoa Kajang Di Kabupaten Bulukumba).

Beni Sumardiana. (2016). Formulasi kebijakan penanganan tindak pidana berbasis isu sara dalam pemilu.

BNPT. Strategi menghadapi paham radikalisme terorisme- isis. 2016.

Creswell, John W. (2004). Research Design. Pendekatan Metode Kuaitatif, Kuantitatif Dan Campuran

Danu Ramdana. Formulasi kebijakan Pemerintah Kabupaten Probolinggo Dalam Pemeberdayaan Pelaku Usaha mikro kecil dan menengah(UMKM).

Dunn. William N. Pengantar Analisis Kebijakan Publik ed.2

Hikmawati. (2016). Partisipasi Masyarakat Dalam Perumusan Kebijakan Publik.

Irwan Abdu Nugraha. (2017). Proses formulasi kebijakan penanggulangan kemiskinan.

Irwandi, Endah R. (2017). Analisis konflik antara masyarakat, pemerintah dan Swasta

Jurnal Wacana politik. Proses politik dalam pembentukan regulasi pemilu : Analisa pertarungan kekuasaan. 
Julfi Mubarok. Fenomena Terorisme di Indonesia : Kajian Aspek Teologi, Ideologi dan Gerakan. Jurnal Volume 15 Nomor 2 Desember 2012.

Lilik Ekowati, Mas Roro (2012). Perencanaan Implementasi \& Evaluasi Kebijakan Atau Program.

Makmur. (2006). Filsafat Administrasi.

Muhamad Risqan. Konflik politik dalam pemerintahan lokal(studi kasus pengunduran diri Wakil Bupati jalur perseorangan di Kabupaten Garut Tahun 2011)

Muhammad Ali Zaidan. Pemberantasan tindak pidana terorisme (Pendekatan kebijakan kriminal). Volume 3 Nomor 1 Tahun 2017, 149 s/d 180.

Muhammad Zulfikar.(2017). Virus Ebola di Afrika Barat sebagai ancaman keamanan nasional Amerika Serikat. Kemas Jurnal Analisis hubungan internasional volume 6 nomor 1 Januari 2017.

Natalia Budi Darma. (2018). Kebijakan formulasi hukum pidana dalam penanggulangan tindak pidana terorisme di Indonesia

Prasetyo (2014). Perubahan Corak Terorisme Di Indonesia Tahun 2000 Hingga Tahun 2013.

S.Widjoyo Muridan. (2004). Bahasa, Negara Versus Bahasa Gerakan Mahasiswa.

Solih Muhadi. Ismail Mk. Ahamd Sofwani. Konsep dan kajian perumusan kebijakan publik. Jurnal review politik volume 06, Nomor 02, Desember 2016

Walidun Husein .Penyusunan draft Akademik APBD sebagai formulasi kebijakan publik.

Widodo, Joko. (2006). Analisis Kebijakan Publik.

Yuliyatun Tajuddin. (2016). Sumber Daya Manusia dan konflik sosial dalam organisasi keagamaan.

Zulfi Mubaroq.Fenomena Terorisme di Indonesia:Kajian Aspek Teologi, Ideologi dan Gerakan..Jurnal Volume 15 Nomor 2 Desember 2012. 